\title{
EDITORIAL
}

\section{DIPETALOGASTER MAXIMA OR D. MAXIMUS AS A XENODIAGNOSTIC AGENT}

Schofield 18 has pointed out that under article 30 of the International Code of Zoological Nomenclature maximus becomes maxima since "gaster" is feminine. However the standard work on triatomine taxonomy still refers to the species as D. maximus ${ }^{11}$. Whatever its species name, it refers to the single member of the genus Dipetalogaster characterised by a pleated abdomen and a restricted geographical distribution to the tip of the Baja California peninsula in Mexico ${ }^{17}$. This was possibly an island at one time and the adaption by the bug to ingest large blood meals may have been due to the rarity of suitable hosts. The maximum recorded feed by a single adult female in our laboratory is 4.3 grams ${ }^{3}$. Active during the day they run over the rocks of their habitat to feed on exposed static man ${ }^{12} 17$. This daylight activity and aggression (which is only surpassed by Rhodnius prolixus) favour its use in xenodiagnosis. In 1974 the author made the largest collection to date of this species (185 specimens). Fifty percent were first instar and after much labour only four adults were captured in the field. Only one of 124 wild bugs had a recognisable blood meal and this was human 12 . There is evidence that they also feed on lizards and woodrats (Neotoma species) ${ }^{17}$. However they proved difficult to adapt in the laboratory in Brasilia to feeding on birds and many were lost before a colony was established.

The main reason for establishing a laboratory colony of this species was to facilitate research on insect derived Trypanosoma cruzi since D. maximus is readily infected and produces large volumes of faecal flagellates. Indeed it has been used subsequently in several laboratories for this purpose 920 . We in Brasilia investigated the susceptibility of $D$. maximus to Brazilian strains of $T$. cruzi at first in São Felipe, Bahia $^{2}$, and subsequently in Goiás ${ }^{7813}$. These studies follow a sequence of investigations of the stages of triatomine used and method of examination after xenodiagnosis. They were all monitored by a statistician to achieve significance and some observations were repeated several times. We were cautious because it seemed odd that D. maximus would incubate $T$. cruzi from central Brazil better than Triatoma infestans the local vector, but this proved to be the case. First instar D. maximus proved as effective as third instar $T$. infestans in isolating T. cruzi from patients with chronic infections and rearing costs are reduced as a result.

\section{DIPETALOGASTER MAXIMA OU D. MAXIMUS COMO AGENTE NO XENODIAGNÓSTICO}

Schofield 18 acentuou que pelo artigo 30 do Código de Nomenclatura Zoológica Internacional deve-se usar maxima ao invés de maximus, em vista do "gaster" ser feminino. Contudo, o principal trabalho sobre taxonomia dos triatomineos ainda refere à espécie como $D$. maximus ${ }^{11}$. Qualquer que seja o nome da espécie, ele se refere a um único membro do gênero Dipetalogaster caracterizado pelo abdome pregueado e distribuição geográfica restrita à ponta da Península da Baixa Califórnia, no México ${ }^{17}$. Esta era, no passado, provavelmente uma ilha e o fato do triatomineo ingerir grande quantidade de sangue pode ter sido um modo de se adaptar à raridade dos hospedeiros apropriados. A quantidade máxima de sangue ingerida por um adulto fêmea em nosso laboratório foi de $4,3 \mathrm{~g}^{3}$.

Os triatomineos são ativos durante o dia, se locomovendo sobre as rochas do "habitat" para se alimentar em alguma pessoa em repouso 1217 . Sua atividade diurna e sua agressividade (ultrapassado somente pelo Rhodnius prolixus) favorece seu uso no xenodiagnóstico. Em 1974, o autor conseguiu a maior coleta, até o momento, desta espécie (185 espécimes). Cinqüenta por cento foi de 19 estádio e somente após muita luta 4 adultos foram capturados no campo. Apenas 1 dos 124 triatomíneos examinados teve a natureza da alimentação avaliada. E esta foi de sangue humano ${ }^{12}$. Existe evidência que esses triatomíneos também se alimentam de lagartixas e ratos de campo (Neotoma sp.) ${ }^{17}$. No entanto, foi difícil sua adaptação no laboratório, em Brasilia, com alimentação em aves. Muitos morreram antes de ser estabelecida a colônia.

A principal razão para o estabelecimento de uma colónia desta espécie no laboratório foi para possibilitar a pesquisa de Trypanosoma cruzi no inseto, visto que o $D$. maximus é facilmente infectado e produz grande volume de flagelado nas fezes. Deste modo, ele vem sendo usado em vários laboratórios com tal finalidade 920 . Nós, em Brasilia, investigamos a susceptibilidade do $D$. maximus para cepas brasileiras de $T$. cruzi, iniciando-se em São Felipe, Bahia ${ }^{2}$, e em Goiás 7813 . Estes estudos seguem uma sequêencia de investigações sobre os estádios dos triatomineos empregados e o método de exames após o xenodiagnóstico. Foram analisados sob o ponto de vista de significação estatistica e algumas observaçōes foram repetidas várias vezes. Seguimos com cuidado porque nos pareceu estranho que o D. maximus pudesse incubar T. cruzi do Brasil Central melhor que o vetor local Triatoma infestans, e isso foi confirmado. 
Editorial. Dipetalogaster maxima ou D. maximus como agente no xenodiagnóstico. Philip Davis Marsden. Revista da Sociedade Brasileira de Medicina Tropical 19:: 205-207, Out-Dez, 1986

We have published our data on mass rearing of D. maximus ${ }^{3}$. Several laboratories have had difficulty in rearing a colony for xenodiagnosis. More ova are produced at temperature of $28-30^{\circ} \mathrm{C}$ and a humidity of $50-60 \%$ but females live a shorter time and total egg production is less than at room temperature. Actually since the first instar is used in xenodiagnosis D. maximus is reared like battery hens; females dropping eggs through the wire mesh into the drawer of the cage designed by Cerisola ${ }^{5}$. The pots for xenodiagnosis are marked with the date after which they may be used allowing 30 days for egg eclosion and one week for consumption of the fat body ${ }^{3}$. It is best to maintain males and females together as egg fertility is higher (Soares VA: personal communication). The young stages are best reared in circular glass jars $24.5 \mathrm{~cm}$ in diameter and $10 \mathrm{~cm}$ high covered with gauze netting. Our colony currently produces approximately 2,000 eggs per month and costs 200 American dollars to maintain ( 10 cents per egg). Each xenodiagnosis of 40 first stage bugs costs 4 dollars. Another small advantage in maintaining this bug is that it has little smell compared with other triatomines 14 .

First stage $D$. maximus has other advantages as a xenodiagnosis agent. It is relatively resistant to starvation and can live up to four months without food $^{3}$. It feeds readily and produces little skin reaction $^{6}$. Rhodnius prolixus, another aggressive feeder, produces such marked skin reactions that artificial xenodiagnosis is commonly used in Venezuela 4 . We observed some mortality in first stage $D$. maximus when used in large numbers for xenodiagnosis in the field ${ }^{13}$. Subsequent work suggests that they die readily on exposure to direct sunlight and should be projected against high temperatures and low humidities during transit 10 . Overcrowding does not seem to be a particular problem with this stage (Schofield CJ: unpublished observations).

Another aspect of the use of D. maximus for xenodiagnosis is related to the possibility that bugs insusceptible to $T$. cruzi existed in our colony. The only experiment we have done in this regard showed that such refractory individuals are rare when exposed to a Bahian strain of $T$. cruzi ${ }^{19}$.

For many years now in Brasilia we have only used first stage $D$. maximus for xenodiagnosis and many workers have used it both for human and animal xenodiagnosis. We have also found it of use as a biological test agent for insecticide activity both in the laboratory and the field ${ }^{15}$. It is slightly less susceptible to insecticide activity than $T$. infestans (Soares VA: unpublished observations). We have been surprised to find that some groups are still searching for a suitable xenodiagnostic agent without trying $D$. maximus ${ }^{16}$, inspite of recent confirmation of its efficacy in incuba-
Larvas do 1\% estádio do D. maximus foram tão eficientes quanto as do $3 \circ$ estádio do $T$. infestans no isolamento do $T$. cruzi de pacientes com infecções crônicas, a custos mais reduzidos.

Já publicamos nossos dados sobre criação do D. maximus em larga escala ${ }^{3}$. Vários laboratórios tiveram dificuldade de criar colônia para xenodiagnóstico. Mais ovos são produzidos à temperatura de 28 a $30^{\circ} \mathrm{C}$ e com a umidade de $50-60 \%$, porém as fêmeas duram menos e a produção total de ovos é menor do que na temperatura ambiental. Como as larvas do 10 estádio são usadas no xenodiagnóstico, o D. maximus seria como galinha na chocadei$\mathrm{ra}$, as fêmeas põem ovos sobre uma tela de aço que caem na caixa desenhada por Cerisola ${ }^{5}$. As caixas para o xenodiagnóstico são marcadas com data de uso, levando-se em conta 30 dias para a eclosão do ovo e uma semana para consumo da gordura do corpo ${ }^{3}$.

É conveniente manter os machos e as fêmeas juntos para melhor fertilidade dos ovos (VA Soares: comunicação pessoal). Os estágios imaturos são criados em jarros de vidro circulares de $24,5 \mathrm{~cm}$ de diâmetro por $10 \mathrm{~cm}$ de altura, cobertos com gaze para melhor crescimento da espécie. Nossa colónia produz habitualmente cerca de 2.000 ovos por mês, ao custo de manutenção de 200 dólares americanos (10 centavos por ovo). Cada xenodiagnóstico com 40 larvas do 1 ? estádio custa 4 dólares. Outra pequena vantagem na forma de manutenção desta espécie é que ela tem pouco odor comparada com outros triatomíneos ${ }^{14}$.

Larvas do 1 o estádio do D. maximus apresentam outras vantagens para o xenodiagnóstico. Elas são relativamente resistentes ao jejum e podem sobreviver até 4 meses sem alimento ${ }^{3}$. Sua alimentação é fácil e produz pouca reação de pele ${ }^{6}$. $R$. prolixus, um outro alimentador agressivo, provoca reações de pele tão marcantes que o diagnóstico artificial é comumente empregado na Venezuela 4 . Observamos alguma mortalidade nas larvas do 1 ? estádio do $D$. maximus quando são utilizadas em grande número no uso do xenodiagnóstico no campo ${ }^{13}$. As subseqüentes pesquisas mostraram que os triatomineos morrem facilmente quando expostos diretamente à luz do sol, devendo ser protegidos contra altas temperaturas e baixas umidades durante o trânsito para o campo ${ }^{10}$. A alta densidade populacional não apresenta prejuizo a este estágio (CJ Schofield: observações não publicadas).

Outro aspecto do uso de D. maximus no xenodiagnóstico se refere à possibilidade de que existam, em nossa colônia, triatomineos não susceptiveis ao $T$. cruzi. A única experiência nesse sentido mostrou que esses individuos refratários são raros quando expostos a uma cepa baiana de $T$. cruzi ${ }^{19}$.

Durante muitos anos estamos usando em Brasilia somente larvas do $D$. maximus no xenodiagnós- 
Editorial. Dipetalogaster maxima ou D. maximus como agente no xenodiagnóstico. Philip Davis Marsden. Revista da Sociedade Brasileira de Medicina Tropical 19: 205-207, Out-Dez, 1986.

ting T. cruzi ${ }^{1}$. It will be of interest to see if this species is as useful in other parts of Brazil and South America as it has been here in Brasilia.

\section{REFERENCES}

1. Alvarenga NJ, Bronfen E. Integração do Trypanosoma cruzi com diferentes vetores: uso para o xenodiagnóstico. Revista da Sociedade Brasileira de Medicina Tropical 17: 145-149, 1984.

2. Barreto AC, Marsden PD, Cuba CC, Alvarenga NJ. Estudo preliminar sobre o emprego de Dipetalogaster maximus (Uhler 1894) (Triatominae) na técnica do xenodiagnóstico em forma crônica da doença de Chagas. Revista do Instituto de Medicina Tropical de São Paulo 20: 183-189, 1978.

3. Barreto AC, Prata AR, Marsden PD, Cuba CC, Trigueiro CP. Aspectos biológicos e criação em massa de Dipetalogaster maximus (Uhler 1894) (Triatominae). Revista do Instituto de Medicina Tropical de São Paulo 23: 18-27, 1981.

4. Cedillos RA, Torrealba JW, Tonn RJ, Mosca W, Ortegon A. El xenodiagnóstico artificial en la enfermedad de Chagas. Boletin de la Oficina Sanitaria Panamericana 93: 240-249, 1982.

5. Cerisola JA, Rohwedder RW, Segura EL, Del Prado CE, Alvarez M, Martini GJW. El xenodiagnóstico. Monografia. Instituto Nacional de Diagnóstico e Investigación de la Enfermedad de Chagas "Dr. Mario Fatala Chaben". Buenos Aires, Argentina, 1974.

6. Costa CHN, Costa MT, Weber JN, Gilks CF, Castro C, Marsden PD. Skin reactions to bug bites as a result of xenodiagnosis. Transactions of the Royal Society of Tropical Medicine and Hygiene 75: 405-408, 1981.

7. Cuba CC, Alvarenga NJ, Barreto AC, Marsden PD, Chiarini C. Nuevos estudios comparativos entre Dipetalogaster maximus y Triatoma infestans en el xenodiagnóstico de la infección chagásica crónica humana. Revista do Instituto de Medicina Tropical de São Paulo 20: 145-151, 1978.

8. Cuba CC, Alvarenga NJ, Barreto AC, Marsden PD, Macêdo V, Gama MP. Dipetalogaster maximus (Hemiptera, Triatominae) for xenodiagnosis of patients with serologically detectable Trypanosoma cruzi infection. Transactions of the Royal Society of Tropical Medicine and Hygiene 73: 524-527, 1979.

9. Garcia ES, Dvorak JA. Growth and development of two Trypanosoma cruzi clones in the arthropod Dipetalogaster maximus. American Journal of Tropical Medicine and Hygiene 31: 259-262, 1982.

10. Johnson CE, Oakley EF, Marsden PD. Mortality of Dipetalogaster maximus (Uhler) in response to temperature and humidity. Revista da Sociedade Brasileira de Medicina Tropical 17: 17-20, 1984.

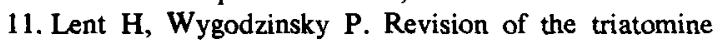
(Hemiptera, Reduviidae) and their significance as vectors of Chagas' disease. Bulletin of the American Museum of Natural History. Vol. 163, Art. 3, New York, 1979. tico e muitos pesquisadores já utilizam esta espécie em xenodiagnóstico humano e em animais. Foi mostrado também um agente biológico de importância para testar a atividade do inseticida em laboratório e no campo ${ }^{15}$. É menos susceptivel à atividade do inseticida comparativamente ao $T$. infestans (VA Soares: observaçōes não publicadas). Estranhamos que alguns grupos tentem encontrar um agente mais eficaz para o xenodiagnóstico sem experimentar $o$ D. maximus ${ }^{16}$, embora haja confirmação recente sobre a eficácia desta espécie para incubar o $T$. cruz $i$. Seria interessante saber se esta espécie é tão útil em outras partes do Brasil e da América do Sul, como está sendo aqui em Brasilia.

12. Marsden PD, Cuba CC, Alvarenga NJ, Barreto AC. Report on a field collection of Dipetalogaster maximus (Hemiptera, Triatominae) (Uhler, 1894). Revista do Instituto de Medicina Tropical de São Paulo 21: 202 206, 1979.

13. Marsden PD, Barreto AC, Cuba CC, Gama MP, Ackers J. Improvements in routine xenodiagnosis with first instar Dipetalogaster maximus (Uhler 1894) (Triatominae). American Journal of Tropical Medicine and Hygiene 28: 649-652, 1979.

14. Mazzotti L. Ausencia de emanaciones odoriferas perceptibles en Dipetalogaster maximus. Algunos comentarios sobre esta especie. Revista do Instituto de Medicina Tropical de São Paulo 12: 320-324, 1970.

15. Penna R, Bosworth A, Brasil IA, Marsden PD. Persistence of the residual activity of BHC on the surface of different building materials. Revista da Sociedade Brasileira de Medicina Tropical 17:95-99, 1984.

16. Perlowagora-Szumlewicz A, Müller CA. Studies in search of a suitable experimental insect model for xenodiagnosis of hosts with C hagas' disease. 1. Comparative xenodiagnosis with nine triatomine species of animals with acute infections by Trypanosoma cruzi. Memórias do Instituto Oswaldo Cruz 77: 37-53, 1982.

17. Ryckman RE, Ryckman AE. Epizootiology of Trypanosoma cruzi in South Western North America. Part X. The biosystematics of Dipetalogaster maximus in Mexico (Hemiptera, Reduviidae) (Kinetoplastida, Trypanosomidae). Journal of Medical Entomology 4: 180-188, 1967.

18. Schofield CJ. The behaviour of triatominae (Hemiptera, Reduviidae): a review. Bulletin of Entomological Research 69: 363-379, 1979.

19. Torno CO, Soares V, Cuba CC, Barreto AC, Alvarenga NJ, Marsden PD. A case of xenodiagnosis. Revista do Instituto de Medicina Tropical de São Paulo 23: 229 $232,1981$.

20. Zeledon R, Alvarenga NJ, Schosinsky K. Ecology of Trypanosoma cruzi in the insect vector. In: Chagas' disease. P. 59-70. Pan American Health Organisation. Scientific Publication No. 347, Washington, 1977. 